\title{
Lesion development and conidial production of Neonectria ditissima on apple trees in four New Zealand regions
}

\author{
Reiny W.A. Scheper ${ }^{1, *}$, Lizelle Vorster ${ }^{2}$, Lauren Turner ${ }^{2}$, Rebecca E. Campbell ${ }^{2}$, Kate Colhoun ${ }^{3}$, \\ Danielle McArley ${ }^{4}$, Rosalind Murti ${ }^{5}$, Andrew Hodson ${ }^{6}$, Robert Beresford ${ }^{7}$, Maryam Stock ${ }^{1}$, \\ Brent M. Fisher ${ }^{1}$, Duncan I. Hedderley ${ }^{8}$ and Monika Walter ${ }^{2}$ \\ ${ }^{1}$ The New Zealand Institute for Plant and Food Research Ltd (PFR), Private Bag 1401, Havelock \\ North 4130, New Zealand \\ ${ }^{2}$ PFR, Old Mill Road, Motueka, 7198, New Zealand \\ ${ }^{3}$ PFR, 990 Earnscleugh Road, RD 1, Alexandra, 9391, New Zealand \\ ${ }^{4}$ Fruition, 94 Anderson Road, Whakatu, Hastings, 4180, New Zealand \\ ${ }^{5}$ Stirling Drive, Morrinsville, 3300, New Zealand \\ ${ }^{6}$ Rowan House, 429 Gloucester Street, Taradale, Napier 4112, New Zealand \\ ${ }^{7}$ PFR, Private Bag 92 169, Mt Albert, Auckland 1142, New Zealand \\ ${ }^{8}$ PFR, Batchelar Road, Palmerston North 4474, New Zealand \\ *Corresponding author: reiny.scheper@plantandfood.co.nz
}

\begin{abstract}
This study examined incubation period, lesion length and conidial release in Neonectria ditissima (European canker) in four New Zealand regions in relation to climatic factors. Incubation period was studied on potted 'Royal Gala' trees inoculated with $N$. ditissima. One week after inoculation, symptomless trees were dispatched to Waikato, Hawke's Bay, Tasman, Otago and positive controls remained in a glasshouse. Conidial release was studied in trees with lesions that were dispatched to the same regions. Rain traps were placed under each lesion and conidia quantified after each rain event. Disease progress and conidial production were examined in relation to weather. Lesions developed significantly slower in Otago and faster in Waikato and the glasshouse, compared with Tasman and Hawke's Bay. Symptom development accelerated with increasing daily hours of $11-16^{\circ} \mathrm{C}$ and humidity (74.6-87.2\% RH). The highest conidium counts occurred in Waikato and the lowest in Otago, while conidial production started earlier in Tasman than elsewhere. Temperature is the main driver for symptom development during the incubation period and rainfall is not required. Rainfall frequency drives conidial production.
\end{abstract}

Keywords European canker, Neonectria galligena, Nectria galligena, conidial production, incubation period, latent infection, climate, rainfall, temperature.

\section{INTRODUCTION}

European canker, caused by the fungus Neonectria ditissima, is a serious disease of apples in temperate high-rainfall climates, where frequent rainfall stimulates conidial production, dispersal and infection (McCracken et al. 2003; Weber 2014; Amponsah et al. 2017). The disease can result in death of buds, shoots, spurs and branches (English et al. 1979), and sometimes whole trees.

Beresford \& Kim (2011) found that severe canker problems occur in regions of the world where there is an average of $>8 \mathrm{~h} /$ day with temperatures between 11 and $16^{\circ} \mathrm{C}$ in at least 5 months of the 
year and rainfall occurs on $>30 \%$ of days in those months. The risk of European canker increases as these thresholds are exceeded more often and by greater amounts. The canker risk in the reference areas used by Beresford \& Kim (2011) was determined from the literature and was based on the effect of tree cankers and fruit rots on apple production. This would, therefore, include the disease cycle processes of conidial production and dispersal, conidial germination, infection, incubation period (time to first symptoms), latent period (time to new conidia), the speed by which lesions girdle and kill plant tissue and the increase of canker incidence in apple orchards. The above empirical thresholds may not apply to each of these factors individually. For example, rainfall frequency is known to affect conidial production, dispersal and infection (Dubin \& English 1974, 1975; Swinburne 1975), but whether rainfall frequency or amount affects incubation period or the speed at which lesions girdle and kill plant tissue is unknown.

In this study, the effect of regional differences on: (1) the development of canker symptoms; and (2) conidial production was examined. In addition, the effect of temperature, relative humidity $(\mathrm{RH})$ and rainfall on incubation period and lesion expansion was explored.

\section{MATERIALS AND METHODS}

There were two parallel experiments: the first on incubation period, using observations of symptom development; and the second on conidial release, using rain traps. For the incubation-period experiment, wounds were inoculated and plants held for 1 week under disease-conducive conditions and then shipped to the four regions (details below), whereas for the conidial-release experiment, plants were inoculated, kept until symptoms developed and then shipped to the regions.

\section{Plant material}

\section{Incubation period}

'Royal Gala' trees, grafted onto 'M793' rootstock were potted into $3.5-\mathrm{L}$ plastic planter bags
(PB6.5) in winter 2014. They were maintained on the Hawke's Bay hardstand of The New Zealand Institute for Plant and Food Research Limited (PFR). In winter 2015 and 2016, the trees were cut back to just one bud, above the graft union. They did not receive fertiliser after spring 2016. On 11 July 2018, 30 trees were re-potted in larger 12-L (PB28) bags. The potting mix contained starter fertilisers to promote root growth, but no slow-release fertilisers.

\section{Conidial release}

'Royal Gala' trees, grafted onto 'M27' rootstock were potted into planter bags (PB28) in spring 2017. Plants were fertilised with calcium ammonium nitrate (20 g/plant) in autumn 2018. They were maintained outside on the PFR hardstand at Motueka.

In both experiments, plants were watered directly into the soil in the pots by automated drip irrigation (Otago, Motueka) or by hand (Hawke's Bay, Waikato) as required. Care was taken not to wet the trees when watering.

\section{Inoculation and trial design}

In both experiments, wounds were created using a rasp (Bus et al. 2019), and artificially inoculated with $N$. ditissima conidial suspension $\left(5 \times 10^{5}\right.$ conidia $\mathrm{mL}^{-1}$ in sterile distilled water) prepared on 11 January 2018 using field-collected cankers in Tasman (Scheper et al. 2015; Walter et al. 2016). The conidial suspension was stored frozen at $-18^{\circ} \mathrm{C}$ until used (Scheper et al. 2015; Orchard et al. 2018). Inoculations for the conidial release experiment were done on 6 June 2018 and for the incubation period experiment on 20 July 2018. The same inoculum was used, hence for the July inoculation the conidia had been frozen, thawed, refrozen and thawed again. The conidial germination rate of the inoculum, as determined on glass slides, was $83 \%$ (June) and 43\% (July).

\section{Incubation period}

On 20 July 2018, 30 trees were placed inside a glasshouse at the PFR Hawke's Bay site and wounded. Each tree received three or four rasp wounds on the central leader (2-year-old wood) 
as well as three to six on lateral shoots (1-yearold wood), with only one wound per lateral shoot. The trees were divided into five groups of six trees. Each group of six trees with 48 wounds in total was destined for a different region. The wounds were artificially inoculated with $20 \mu \mathrm{L}$ conidial suspension using a pipette.

After the inoculation, the $\mathrm{RH}$ in the glasshouse was increased to $100 \%$ for 2 days. The temperature in the glasshouse during inoculation was $18.5-20.5^{\circ} \mathrm{C}$. While the humidity was $100 \%$, the temperature dropped to $4.5^{\circ} \mathrm{C}$ at night and reached $23^{\circ} \mathrm{C}$ during the day, and the average temperature was $13^{\circ} \mathrm{C}$. After the 2-day period of $100 \%$ humidity, the humidity was kept at $80 \%$ until the trees were transported to their destination. The temperature in the glasshouse during this time was $3.5-26.5^{\circ} \mathrm{C}$ with an average of $10.8^{\circ} \mathrm{C}$. On 26 July 2018 , the trees were wrapped individually in cling wrap to prevent branches breaking during transport. One group of six trees remained in the glasshouse under $80 \% \mathrm{RH}$ and were considered to be the positive control group. On 27 July, a second group of six trees were transported to their location in Hawke's Bay (Whakatu), and the remaining trees were picked up for transport (six each) to Waikato (Morrinsville), Tasman (Riwaka) and Otago (Clyde). These trees were in transport for approximately 1 week and the temperature during this time is unknown. When the trees arrived at their destination they were unwrapped and placed outside in an open area, away from apple trees. No canker symptoms were visible at the time of arrival. Trees were watered when required as described above, depending on rainfall. Trees in the glasshouse were watered directly to the soil in the pots by automated drip irrigation, the central leader and lateral shoots were never wetted.

\section{Conidial release}

On 6 June 2018, rasp wounds were made on three to four horizontal shoots per plant (single wound/ shoot at approximate midpoint of the shoot) on 28 plants and inoculated with approximately 20-30 $\mu \mathrm{L} N$. ditissima conidial suspension with a brush method, as described by Walter et al. (2016). The first lesions developed in early August 2018. Only one shoot with symptoms was selected per plant, the remaining shoots were cut. The minimum lesion size was $\sim 8 \mathrm{~mm}$, with lesions ranging from 8.4 to $39.7 \mathrm{~mm}$, and an average lesion size of 21.6 $\mathrm{mm}$. Lesions were measured on 26 August 2018 and seven trees/region were shipped as described above on 27 August 2018, arriving within 2 days. The sites for the conidial release experiment were the same as above in Waikato, Tasman and Otago, but the Hawke's Bay site was in Taradale. Upon arrival at the sites, rain traps were attached below the lesion as described by Walter et al. (2018). After each rain event, rain traps were collected, stored frozen, and shipped to PFR Motueka for enumeration (Walter et al. 2018), and new traps were deployed in their place. There was no glasshouse treatment for this experiment.

A rain event constituted a single non-disrupted rainfall event for one or multiple days, as well as multiple rainfall/showers during 1-2 days. In either case, sufficient water $(1 \mathrm{~mL})$ needed to be collected in the rain traps, before rain traps were changed.

The volume of water collected in the rain traps was recorded, conidia concentrated and counted to determine total conidia captured by rain event (Walter et al. 2018). The actual rainfall data were obtained from the local weather stations.

\section{Symptom development}

The presence of lesions was recorded regularly, starting 3.5 weeks after inoculation (WAI). The last assessment in each location depended on the speed of symptom development, with trees in the glasshouse, Hawke's Bay and Waikato assessed until 12 WAI, trees in Tasman until 13 WAI, and trees in Otago until 26 WAI. The trees in the glasshouse and in Tasman were assessed weekly, those in Hawke's Bay had six assessments in 7.5 weeks, in Waikato 12 assessments in 8.5 weeks and those in Otago eight assessments in 21 weeks. The presence of lesions was scored by assigning each wound a score of either no canker symptoms, early canker symptoms $(<6$ $\mathrm{mm}$ with slight cracking or flaking of the bark) 
or definite European canker symptoms (>6 mm and characteristic lesion shape).

Lesion length was measured twice in each location, eight and $12 \mathrm{WAI}$, plus an extra measurement at $16 \mathrm{WAI}$ in Otago. Lesion length was recorded only for definite canker lesions.

Wounds (three in total) that did not develop any symptoms were excised and placed on apple sap amended water agar (ASAWA) as described by Amponsah et al. (2014) to determine whether an asymptomatic infection with $N$. ditissima was present.

\section{Statistical analysis}

The disease progress in the five locations was compared by calculating the area under the disease progress curve (AUDPC) from the proportion of wounds with symptoms, for the central leader and the lateral shoots of each tree (both early and definite), and the time in weeks until 12 WAI. The AUDPC was analysed using analysis of variance (ANOVA), with tree within region as a block term, and region and central leader vs lateral position as treatment factors, weighted by the number of wounds of each type on each tree.

For the central leader and the lateral shoots of each tree, the time after inoculation when the first wound showed early symptoms and when the first wound showed definite canker lesions were analysed with split-plot ANOVA, with each tree being a main plot and the two types of wounds the sub-plots. This was repeated for the time when all infected wounds showed possible symptoms and when they all showed canker lesions.

The average lesion length for the central leader and the lateral shoots of each tree was log-transformed to stabilise variance and then analysed using linear mixed models. Bonferroni adjusted Least Significant Differences $(\alpha=0.05)$ were used to determine statistical differences in mean lesion size between wound types and regions. Statistical analyses were carried out using GenStat software (version 17, 2014, VSNi Ltd, Hemel Hempstead, UK).

Weather data
Hourly weather data from weather stations in Rukuhia (Waikato), Waipatu (Hawke's Bay, Whakatu), Pakowhai (Hawke's Bay, Taradale), Riwaka (Tasman) and Clyde (Otago) were downloaded from MetWatch Online (www. metwatch.co.nz). Hourly temperature data were recorded in the glasshouse using iButtons (model DS1921G; iButtonLink, WI, USA).

In each location, the average temperature, average $\mathrm{RH}$, total rainfall, number of rain events, average rain event duration, average rainfall per rain event and the rainfall frequency (percentage of days with rain) were calculated over the 10week period of 2-12 WAI. It was assumed that rainfall occurred on days with precipitation $>0.25$ $\mathrm{mm}$. A rain event in the 'incubation period' trial, constituted a single non-disrupted rainfall event that could last several hours or multiple days. The definition in the 'conidial release' trial is described above. In addition, for each location the daily average hours with a temperature of 11$16^{\circ} \mathrm{C}$ and $11-24^{\circ} \mathrm{C}$ and the daily average hours with $\mathrm{RH} \geq 80 \%$ were calculated.

\section{RESULTS \\ Incubation period}

\section{Symptom appearance}

Analysis of the AUDPC showed that symptom appearance differed significantly with region $(\mathrm{P}<0.001)$, but not with wound position (central leader or lateral shoots), either overall $(\mathrm{P}=0.79)$ or the interaction with region $(\mathrm{P}=0.51)$. Trees outdoors in Waikato and the Hawke's Bay glasshouse had a significantly higher AUDPC than all the other regions, while the AUDPC for trees outdoors in Hawke's Bay and Tasman were significantly higher than in Otago (Table 1). Early symptoms were recorded within 6 WAI in all locations, but in Waikato and the Hawke's Bay glasshouse more than $47 \%$ of wounds had either early symptoms or cankers within 4 WAI (Fig. 1).

In the Hawke's Bay glasshouse and in Tasman, one wound did not have any symptoms 13 WAI, and when placed on ASAWA, no $N$. ditissima was isolated. These wounds were excluded from subsequent analyses as they were not infected, 


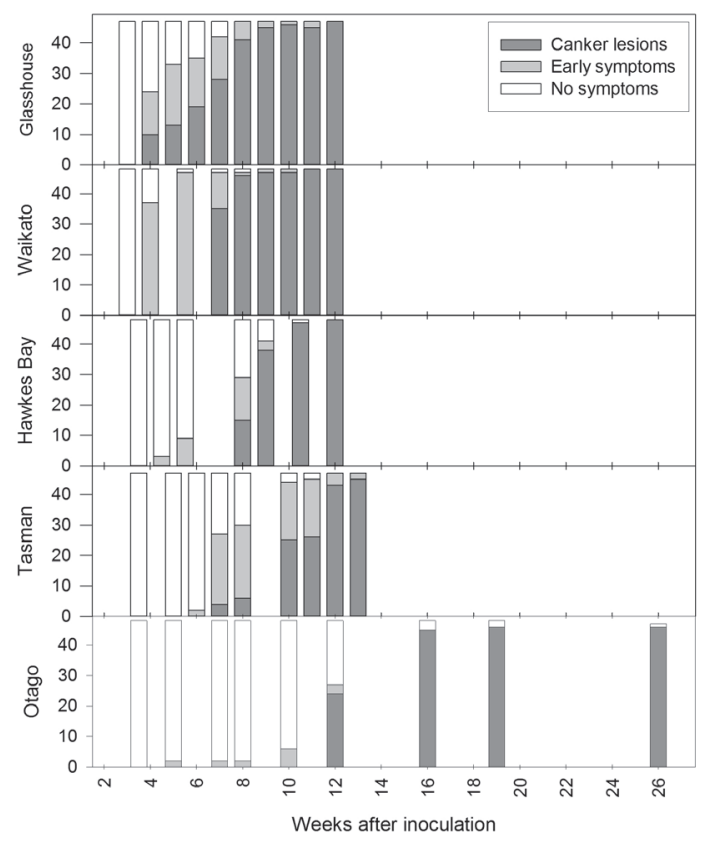

Figure 1 Symptom development over time in four regions of New Zealand compared with controlled conditions in a glasshouse. The number of infected wounds in potted 'Royal Gala' trees that showed no symptoms, early symptoms and canker lesions are shown at each assessment time.

probably because they had not been inoculated. In Otago, one wound did not have any symptoms 26 WAI, but this wound had a symptonless infection because $N$. ditissima was isolated when placed on ASAWA. In the analysis comparing the regions regarding the time at which all infected wounds showed symptoms or had lesions, this wound with symptomless infection was treated as showing symptoms at 27 WAI.

After analysis of the first occurrence of early symptoms and cankers, and when all infected wounds had symptoms and canker lesions, the results showed that the regions differed significantly $(\mathrm{P}<0.001)$. However, the wound position and the interaction with region were not significant $(\mathrm{P}=0.29)$. For trees in the glasshouse, the first canker lesions appeared significantly earlier than the other locations while, in Otago, the first canker lesion appeared significantly later than any other location. In Waikato and in the glasshouse, total symptom expression of all infected wounds occurred significantly earlier than in the other regions, while in Otago this event happened significantly later (Table 1).

Analysis of the canker lesion length showed that at 8 WAI the main effects of region and wound position were not significant $(\mathrm{P}=0.522$ and $\mathrm{P}=0.247$, respectively), but the interaction was $(\mathrm{P}=0.006)$. In most regions, lesions on the central leader and lateral shoots had similar lengths, but in Tasman, the cankers on the lateral shoots were significantly larger than on the central leaders (data not shown), while in Otago, no canker lesions were present.

At 12 WAI, the main effect of region was significant $(\mathrm{P}<0.001)$, but the main effect of central leader vs lateral was not $(\mathrm{P}=0.69)$, nor was the interaction $(\mathrm{P}=0.25)$. Trees in Hawke's Bay and Waikato had significantly longer lesions than trees in the other regions. Lesions in the glasshouse were similar in length to those in Tasman and Waikato (Table 1).

\section{Weather data}

The average temperature over the 10 -week period of 2-12 WAI was highest in the glasshouse and lowest in Otago (Table 2). The four regions had similar maximum temperatures of $22-23.9^{\circ} \mathrm{C}$ but, as expected, the maximum temperature in the Hawke's Bay glasshouse was much higher $\left(34.5^{\circ} \mathrm{C}\right)$. The glasshouse had the highest daily average hours with a temperature of $11-16^{\circ} \mathrm{C}$ and $11-24^{\circ} \mathrm{C}$ and Otago the lowest. Relative humidity was highest in Waikato and lowest in Otago but the highest rainfall was in Tasman and Waikato, while Hawke's Bay and Waikato received more rain events (Table 3 ). Otago received the lowest rainfall, and the fewest and shortest rain events (Table 3). Temperature, rainfall and $\mathrm{RH}$ variables were almost all positively correlated across the four regions. This was largely driven by the fact that the region with the lowest values for all the temperature variables (Otago) also had the lowest values for all the rainfall and $\mathrm{RH}$ variables and the 
Table 1 Canker symptom development in potted 'Royal Gala' trees in four regions of New Zealand and in a glasshouse after infection occurred: the mean area under the disease progress curve (AUDPC) until 12 weeks after inoculation; the mean time (weeks) after inoculation when the first symptoms and the first cankers were visible, the mean time (weeks) after which all wounds had symptoms or cankers, and the mean lesion length ( $\mathrm{mm}$ ) of cankers, 12 weeks after inoculation. Lesion length was log-transformed for analysis and back-transformed means are presented. The same letter indicates means that were not significantly different based on Bonferroni adjusted least significant difference (LSD).

\begin{tabular}{|c|c|c|c|c|c|c|}
\hline \multirow[t]{2}{*}{ Region } & \multirow[t]{2}{*}{ AUDPC } & $\begin{array}{l}\text { First } \\
\text { early } \\
\text { symptoms }\end{array}$ & $\begin{array}{l}\text { First } \\
\text { definite } \\
\text { symptoms }\end{array}$ & $\begin{array}{l}\text { Early or } \\
\text { definite } \\
\text { symptoms in } \\
\text { all wounds }\end{array}$ & $\begin{array}{l}\text { Definite } \\
\text { symptoms } \\
\text { in all } \\
\text { wounds }\end{array}$ & \multirow[t]{2}{*}{$\begin{array}{l}\text { Lesion } \\
\text { length }\end{array}$} \\
\hline & & \multicolumn{4}{|c|}{ (weeks after inoculation) } & \\
\hline Glasshouse & $707 \mathrm{c}$ & $4.3 \mathrm{ab}$ & $5.3 \mathrm{a}$ & $6.5 \mathrm{ab}$ & $9.2 \mathrm{a}$ & $13.7 \mathrm{ab}$ \\
\hline Waikato & $794 \mathrm{c}$ & $4.0 \mathrm{a}$ & $7.0 \mathrm{ab}$ & $5.8 \mathrm{a}$ & $8.6 \mathrm{a}$ & $21.1 \mathrm{c}$ \\
\hline Hawke’s Bay & $473 \mathrm{~b}$ & $5.8 \mathrm{ab}$ & $8.2 \mathrm{~b}$ & $9.8 \mathrm{ab}$ & $10.0 \mathrm{a}$ & $19.5 \mathrm{bc}$ \\
\hline Tasman & $435 \mathrm{~b}$ & $6.7 \mathrm{~b}$ & $8.4 \mathrm{~b}$ & $10.4 \mathrm{~b}$ & $12.2 \mathrm{a}$ & $13.5 \mathrm{a}$ \\
\hline Otago & $101 \mathrm{a}$ & $10.2 \mathrm{c}$ & $12.7 \mathrm{c}$ & $18.3 \mathrm{c}$ & $18.3 \mathrm{~b}$ & $11.2 \mathrm{a}$ \\
\hline LSD & 125 & 2.4 & 2.4 & 4.2 & 4.0 & $144 \% \#$ \\
\hline
\end{tabular}

\# The back-transformed LSD shows that two means were significantly different if the larger was more than $144 \%$ of the smaller.

Table 2 The average and highest and lowest temperatures, and the daily average hours with a temperature of $11-16^{\circ} \mathrm{C}$ and $11-24^{\circ} \mathrm{C}$, in five locations, over the 10 -week period in which 'Royal Gala' trees with latent Neonectria ditissima infections developed symptoms.

\begin{tabular}{lccccc}
\hline Location/ region & $\begin{array}{c}\text { Average } \\
\text { temperature } \\
\left({ }^{\circ} \mathrm{C}\right)\end{array}$ & $\begin{array}{c}\text { Highest } \\
\text { temperature } \\
\left({ }^{\circ} \mathrm{C}\right)\end{array}$ & $\begin{array}{c}\text { Lowest } \\
\text { temperature } \\
\left({ }^{\circ} \mathrm{C}\right)\end{array}$ & $\begin{array}{c}\text { Hours } \\
11-16^{\circ} \mathrm{C}\end{array}$ & $\begin{array}{c}\text { Hours } \\
11-24^{\circ} \mathrm{C}\end{array}$ \\
\hline Glasshouse & 15.7 & 34.5 & 5.0 & 11.6 & 17.3 \\
Waikato & 10.9 & 22.6 & -0.7 & 9.2 & 11.8 \\
Hawke's Bay & 10.6 & 22.4 & -2.2 & 8.5 & 11.4 \\
Tasman & 10.2 & 23.9 & 0.2 & 7.9 & 10.5 \\
Otago & 7.1 & 22.0 & -5.3 & 4.5 & 5.9 \\
\hline
\end{tabular}

region with the highest values for all temperature variables, except lowest temperature, (Waikato) also tended to have high values for the rainfall and $\mathrm{RH}$ variables.

\section{Relationship between weather and symptom development}

Over the 10-week symptom development period, strong relationships were found between disease progress (AUDPC) and each of the three temperature variables (daily average hours with temperature $11-16^{\circ} \mathrm{C}$, and $11-24^{\circ} \mathrm{C}$, and average temperature). Exponential relationships were the strongest $\left(R^{2} \geq 0.97\right)$, but strong linear relationships were also found. The correlation between disease progress and daily average hours with temperature $11-16^{\circ} \mathrm{C}\left(\mathrm{R}^{2}=0.86\right.$, Fig. 2A) was the strongest, while the correlations between disease progress and daily average hours with temperature $11-24^{\circ} \mathrm{C}$, and between disease progress and average temperature were less strong $\left(\mathrm{R}^{2}=0.80\right.$ for both). Including the Hawke's Bay 
Table 3 The average relative humidity $(\mathrm{RH})$, and the daily average hours with a $\mathrm{RH} \geq 80 \%$, as well as total rainfall, rainfall frequency (percentage of days with rain), number of rain events, average rain event duration and the average rainfall during a rain event, in four New Zealand regions, over the 10-week period in which 'Royal Gala' trees with latent Neonectria ditissima infections developed symptoms.

\begin{tabular}{lccccccc}
\hline Region & & \multicolumn{5}{c}{ Rainfall } \\
\cline { 5 - 8 } & $\begin{array}{c}\text { Average } \\
\text { RH }(\%)\end{array}$ & $\begin{array}{c}\text { Hours } \\
\text { RH } \geq 80 \%\end{array}$ & $\begin{array}{c}\text { Total } \\
(\mathrm{mm})\end{array}$ & $\begin{array}{c}\text { Frequency } \\
(\%)\end{array}$ & $\begin{array}{c}\text { Event } \\
\text { number\# }\end{array}$ & $\begin{array}{c}\text { Event duration } \\
(\mathrm{h}) \#\end{array}$ & $\begin{array}{c}\text { Event } \\
(\mathrm{mm}) \text { \# }\end{array}$ \\
\hline Waikato & 87.2 & 17.7 & 236.7 & 43 & 22 & 13.8 & 11.1 \\
Hawke's Bay & 81.2 & 13.7 & 204.6 & 36 & 24 & 8.7 & 8.4 \\
Tasman & 81.6 & 15.2 & 243.2 & 26 & 14 & 14.6 & 17.2 \\
Otago & 74.6 & 11.5 & 67.6 & 17 & 11 & 8.3 & 5.6 \\
\hline
\end{tabular}

\# A rain event constituted a single non-disrupted rainfall event that could last several hours or multiple days.

glasshouse data weakened these relationships; however the correlation with daily average hours of $11-16^{\circ} \mathrm{C}$ remained strong $\left(\mathrm{R}^{2}=0.80\right)$. $\mathrm{R}^{2}$ values for the other correlations were $\geq 0.59$.

Strong correlations were found between disease progress and average $\mathrm{RH}\left(\mathrm{R}^{2}=0.99\right.$, Fig. $2 \mathrm{~B})$, and disease progress and rainfall frequency $\left(\mathrm{R}^{2}=0.90\right.$, Fig. 2C). Weaker correlations were found between disease progress and total rainfall $\left(\mathrm{R}^{2}=0.70\right)$, the number of rain events $\left(\mathrm{R}^{2}=0.57\right)$ and the average rain event duration $\left(\mathrm{R}^{2}=0.41\right)$. No relationship occurred between disease progress and the average rain volume during a rain event $\left(\mathrm{R}^{2}=0.18\right)$. Disease symptoms developed faster in warmer, humid regions with more rain events.

Similarly, correlations were found between lesion length at $12 \mathrm{WAI}$ and average temperature $\left(\mathrm{R}^{2}=0.70\right)$, and between lesion length and daily average hours with a temperature of $11-16^{\circ} \mathrm{C}$ and $11-24^{\circ} \mathrm{C}\left(\mathrm{R}^{2}=0.76\right.$ and $\mathrm{R}^{2}=0.73$, respectively $)$. However, when glasshouse data were included, no relationship between lesion length and temperature variables were observed $\left(\mathrm{R}^{2}<0.13\right)$.

A strong correlation was observed between lesion length and rainfall frequency $\left(\mathrm{R}^{2}=0.96\right.$, Fig. 2D) and the number of rain events $\left(\mathrm{R}^{2}=0.96\right)$. The correlation with $\mathrm{RH}\left(\mathrm{R}^{2}=0.68\right)$ and total rainfall $\left(\mathrm{R}^{2}=0.42\right)$ was weaker. No correlations were found between lesion length and the rain duration or rainfall amount during a rain event $\left(\mathrm{R}^{2}<0.03\right)$. Lesion expansion, like symptom development, was faster in warmer, humid regions with more rain events.

\section{Conidial release}

There were 20,17, 13 and 11 rainfall events in Waikato, Tasman, Hawke's Bay, and Otago over the period monitored, respectively (Fig. 3). More conidia/lesion/rain event were trapped in Waikato $(159,523)$ than in Tasman $(145,079)$, Hawke's Bay $(30,692)$ and Otago $(4,314)$. All seven Otago trees died by November 2018, presumably because of transport conditions. However, the lesions continued to produce and release conidia and the data were included in the analysis.

Not all lesions were actively releasing conidia at the same time. Individual lesion conidial release activity cycled during the monitoring period. Approximately 64\%, 86\%, 64\% and 14\% of lesions produced conidia at any one rain event, for Waikato, Tasman, Hawke's Bay, and Otago, respectively. The number of conidia collected in the rain traps from an 'active' lesion was not dependent on the amount of rainfall. As little as $0.2 \mathrm{~mm}$ of rain facilitated conidial capture in these small trees with no canopy protection. Generally, if conidia were released from an 'active' lesion the total number trapped/lesion ranged between 700 and 7,300,000 (interquartile range 12,000 to 136,000$)$ conidia per rain event. The average number of conidia released by rainfall amount is shown in Figure 4. 



Figure 2 Significant relationships between climatic factors and both disease progress (AUDPC, area under the disease progress curve) and lesion length in four New Zealand regions. Correlations between the daily average hours with a temperature of $11-16^{\circ} \mathrm{C}$ and disease progress in the four regions: the glasshouse data are shown separately (A); between the average relative humidity and disease progress (B); between the rainfall frequency and disease progress (C); and between the rainfall frequency and lesion length (D).

\section{DISCUSSION}

Large and significant differences in symptom development between the regions were observed, with much faster disease progress and reduced incubation period in Waikato compared with the other regions. No significant differences were observed between Waikato and the more controlled Hawke's Bay glasshouse conditions. Disease progress and incubation period outdoors in Hawke's Bay and Tasman were similar. In Otago, symptoms developed much more slowly than anywhere else. The empirical observations here agree with the theoretical Beresford \& Kim (2011) model identifying European canker risk based on macroclimate. Incubation period, disease progress, lesion expansion and conidial production differed between the four regions.

For the magnitude of disease progress and lesion length, the regions ranked Waikato >
Hawke's Bay > Tasman > Otago. This was also the ranking for average temperature and hence the strong positive associations between temperature, symptom development and disease progress. For the rainfall and $\mathrm{RH}$ variables across the regions, some were positively correlated with symptom development and disease progress. However, because these also tended to be regionally correlated with the temperature variables, it is not possible to conclude whether temperature, rainfall or $\mathrm{RH}$ drive these responses. However, the fact that the fastest symptom development occurred in the glasshouse, which had the warmest temperature and no rainfall (drip irrigation), suggests that rainfall is less important than temperature in initial canker symptom development. This is a reasonable supposition, since incubating infections are inside the plant and not directly affected by external moisture. 


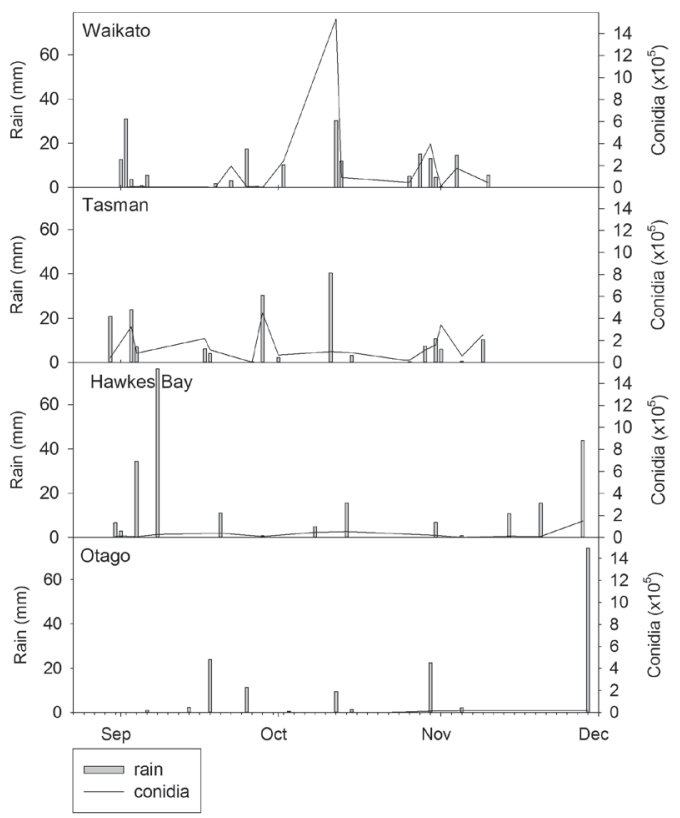

Figure 3 Actual amount of rain and total number of Neonectria ditissima conidia collected in rain traps in four New Zealand regions during spring (September-December) 2018.

The positive correlations between disease progress and $\mathrm{RH}$, and between lesion length and number of rain events suggest that rainfall and $\mathrm{RH}$ both play an important role in the later stages of canker formation.

Average temperature and daily average hours with a temperature of $11-24^{\circ} \mathrm{C}$ correlated less with disease progress when the glasshouse data were included in the analyses. However, daily average hours with a temperature of $11-16^{\circ} \mathrm{C}$ remained a strong predictor of disease progress when the glasshouse data were included, indicating that this temperature range may be important during the incubation period of European canker. It is also possible that the high temperatures that occurred in the glasshouse had a detrimental effect on the disease progress, prolonging the incubation period. The effect of temperatures above $30^{\circ} \mathrm{C}$ on $N$. ditissima infections in woody tissues is unknown. However, since temperatures above $35^{\circ} \mathrm{C}$ are lethal to mycelium grown in vitro (unpublished data), more research on the effect of temperatures $>25^{\circ} \mathrm{C}$ on European canker is warranted.

For both disease progress and conidial release, rainfall frequency appeared to be much more important than total rainfall, the number of rain events or the duration of rain events, while the rainfall amount during rain events had no correlation with disease progress and rain-trap data. This result confirms the importance of using rainfall frequency as a threshold for disease development (Beresford \& Kim 2011).

Significant differences in lesion length among locations were observed only once, at 12 WAI. This confirms previous observations that lesion length is less reliable than disease incidence when comparing disease progress in different treatments (Scheper et al. 2018; Bus et al. 2019).

Rainfall frequency and the number of rain events were the only climatic variables that affected lesion length. This is a further indication that the amount of rainfall and the duration of rain events are less important for European canker development than the frequency. For lesion growth, rainfall frequency may be more important than temperature and $\mathrm{RH}$. Although rain was not required for lesions to lengthen, as shown by the data from the glasshouse, lesions were significantly longer when the Beresford \& Kim (2011) rainfall frequency threshold was exceeded.

Lesion size as an indicator of fungal biomass may affect the conidial production potential of a lesion. Frequent rainfall (and possibly warmer temperatures) was required for conidia to be produced and released in subsequent rain events. The conidial production potential of 'active' lesions was similar, but the cycling duration from an 'active' to an 'inactive' state varied greatly amongst regions. As mentioned, all Otago trees died by November 2018 and conidial release data may, therefore, be compromised. However, data were included, because lesions were established before transport and excised European canker lesions produce similar or greater numbers of conidia than lesions in planta (Walter et al. 2018). A high conidial release was observed 



Figure 4 Relationships between rainfall amount and total number of Neonectria ditissima conidia captured in rain traps during spring (September-December) 2018. Each point is the mean of seven replicate observations per site.

in December 2018. However, Otago conidial release data may be compromised, most likely by increased and not decreased conidial production (Walter et al. 2018). The overall lower disease progress and lower conidial production, however, agrees with earlier research on trees inoculated in Otago. In this earlier research, few inoculation sites developed symptoms and the European canker lesions that had developed, produced few conidia (unpublished data).

The effect of temperature on lesion length needs further investigation. Data from the four regions indicate some effect, but when the glasshouse data were included, no relationship was observed. This could be because the effects of rainfall and temperature on lesion length 
interact, or it could be that the higher maximum temperatures in the glasshouse reduced lesion length.

To separate the effects of temperature, $\mathrm{RH}$ and rainfall frequency on disease progress, lesion growth and conidial production potential more clearly, more research in controlled climate conditions is required. The possible detrimental effect of higher temperatures on disease development needs further investigation as this may identify regions where European canker may not be able to thrive, despite both climatic thresholds (Beresford \& Kim 2011) being exceeded.

\section{CONCLUSIONS}

Temperature is the main driver for development of European canker symptoms during the incubation period, and rainfall is not required. This finding is supported by a strong regional association between temperature and rate of symptom development and by the glasshouse results, where rapid symptom development occurred in the absence of wetting. Rain frequency is, however, a key driver in lesion expansion and conidial production.

The lower risk of European canker development that is commonly observed in Otago is at least partly explained by the longer incubation period and reduced inoculum production revealed in this study. These findings will aid New Zealand apple growers in making timely disease-management decisions regarding the removal of sporulating canker lesions.

\section{ACKNOWLEDGEMENTS}

This work was funded by the Sustainable Farming Fund (SFF404838) between the Ministry for Primary Industries and New Zealand Apples \& Pears Inc., as well as support from The New Zealand Institute for Plant and Food Research Limited. We thank Dr Joanna Bowen, Dr Gareth Hill (PFR) and Rachel Kilmister (New Zealand Apples \& Pears Inc.) for helpful comments on the manuscript draft.

\section{REFERENCES}

Amponsah NT, Walter M, Scheper RWA 2014. Agar media for isolation of Neonectria ditissima from symptomatic and asymptomatic apple tissues and production of infective conidia. New Zealand Plant Protection 67: 116-122.

Amponsah NT, Walter M, Scheper RWA, Beresford RM 2017. Neonectria ditissima spore release and availability in New Zealand apple orchards. New Zealand Plant Protection 70: 78-86.

Beresford RM, Kim KS 2011. Identification of regional climatic conditions favorable for development of European canker of apple. Phytopathology 101: 135-146.

Bus VGM, Scheper RWA, Walter M, Campbell RE, Kitson B, Turner L, Fisher BM, Johnston SL, Wu C, Deng CH, Singla G, Bowatte D, Jesson LK, Hedderley DI, Voltz RK, Chagné D, Gardiner SE 2019. Genetic mapping of the European canker (Neonectria ditissima) resistance locus Rnd1 from Malus 'Robusta 5'. Tree Genetics \& Genomes 15, e25.

Dubin HJ, English H 1974. Factors affecting apple leaf scar infection by Nectria galligena conidia. Phytopathology 64: 1201-1203.

Dubin HJ, English H 1975. Epidemiology of European apple canker in California. Phytopathology 65: 542-550.

English H, Dubin HJ, Schick FJ 1979. Chemical control of European canker of apple. Plant Disease Reporter 63: 998-1002.

McCracken AR, Berrie A, Barbara DJ, Locke T, Cooke LR, Phelps K, Swinburne TR, Brown AE, Ellerker B, Langrell SRH 2003. Relative significance of nursery infections and orchard inoculum in the development and spread of apple canker (Nectria galligena) in young orchards. Plant Pathology 52: 553-566.

Orchard S, Campbell RE, Turner L, Butler RC, Curnow T, Patrick E, Walter M 2018. Longterm deep-freeze storage of Neonectria ditissima conidium suspensions does not reduce their ability to infect apple trees. New Zealand Plant Protection 71: 158-165.

Scheper RW, Fisher BM, Taylor T, Hedderley 
DI 2018. Detached shoot treatments cannot replace whole-tree assays when phenotyping for apple resistance to Neonectria ditissima. New Zealand Plant Protection 71: 151-157.

Scheper RWA, Frijters L, Fisher BM, Hedderley DI 2015. Effect of freezing of Neonectria ditissima inoculum on its pathogenicity. New Zealand Plant Protection 68: 257-263.

Swinburne TR 1975. European canker of apple (Nectria galligena). Review of Plant Pathology 54: 787-799.

Walter M, Roy S, Fisher BM, Mackle L, Amponsah NT, Curnow T, Campbell RE, Braun P, Reineke A, Scheper RWA 2016. How many conidia are required for wound infection by Neonectria ditissima? New Zealand Plant Protection 69: 238-245.

Walter M, Chevalier CE, Turner L, Campbell RE 2018. Neonectria ditissima conidium production and release in planta. New Zealand Plant Protection 71: 174-179.

Weber RWS 2014. Biology and control of the apple canker fungus Neonectria ditissima (syn. N. galligena) from a northwestern European perspective. Erwerbs-Obstbau 56: 95-107. 